\title{
PENINGKATAN SIKAP JUJUR DAN HASIL BELAJAR BAHASA INGGRIS MATERI PROCEDURE TEXT MELALUI MODEL PROJECT BASED LEARNING BERBANTUAN MEDIA POWERPOINT BAGI SISWA KELAS IXB SMP NEGERI 1 BOYOLALI
}

\author{
Bardi \\ SMP Negeri 1 Boyolali \\ Email: bardimpd@yahoo.com
}

\begin{abstract}
The goal of this research is to increase the honest of doing activity and the result of studying English Procedure text through Project Based Learning model using Powerpoint media for the students of IXB State Junior High School 1 Boyolali in semester 1 year 2018/2019. This research is held for the students of IXB State Junior High School 1 Boyolali in semester 1 year 2018/2019. There are 28 students in this class that consists of 6 boys and 22 girls. The students are taught through Project Based Learning using Powerpoint media in 2 cycles, and each cycle consists of planning, acting, observing, and reflecting. In cycle I the students are taught through Project Based Learning using Powerpoint media in a big group of 7 , while in cycle II the students are taught through Project Based Learning using Powerpoint media in small group of 4. The method used in this research is Classroom Action Research (CAR). For data validation, the observation isn't only done by the researcher himself but also collaborate with the students, peers and also using test technique. Data analysis used in this research is descriptive comparative continued with reflection.The result of this research states that through Project Based Learning using Powerpoint media can increase the honest of doing activity and the result of studying English Procedure text for the students of IXB State Junior High School 1 Boyolali in semester 1 year 2018/2019. From initial condition the honest of doing activity is low to the last condition becomes high and the result of the studying English Procedure text from the average of initial condition is 77 to the last conditions becomes 86 or increases 9 points or $11.68 \%$.
\end{abstract}

Keywords: honest, procedure text, result of studying, project based learning, powerpoint

Abstrak. Tujuan penelitian ini adalah untuk meningkatkan sikap jujur dalam mengerjakan tugas dan hasil belajar Bahasa Inggris materi Procedure text melalui penggunaan model Project Based Learning berbantuan media Powerpoint bagi siswa kelas IXB SMP Negeri 1 Boyolali pada semester1 tahun 2018/2019. Penelitian ini dilakukan kepada siswa kelas IXB SMP Negeri 1 Boyolali pada Semester 1 tahun 2018/2019. Jumlah siswa dalam kelas ini adalah 28 siswa yang terdiri atas 6 siswa laki-laki dan 22 siswa perempuan. Siswa diberikan perlakuan pembelajaran dengan menggunakan model Project Based learning berbantuan media Powerpoint dan setiap siklus terdiri atas perencanaan, pelaksanaan, pengamatan, dan refleksi. Proses pembelajaran pada siklus I dilakukan dalam kelompok besar yang terdiri atas 7 siswa, sedangkan proses pembelajaran pada siklus II dilakukan dalam kelompok kecil yang terdiri atas 4 siswa. Metode yang digunakan dalam penelitian adalah Penelitian Tindakan Kelas (PTK). Pengumpulan data melalui observasi dan studi dokumentasi. Untuk validasi data, observasi tidak dilakukan oleh peneliti sendiri, tetapi juga berkolaborasi dengan siswa dan teman sejawat, serta dengan menggunakan teknik tes. Analisis data yang digunakan adalah deskriptif komparatif yang dilanjutkan 
dengan refleksi. Hasil penelitian menyatakan bahwa melalui penggunaan model Project Based Learning berbantuan Media Powerpoint dapat meningkatkan sikap jujur dalam mengerjakan tugas dan hasil belajar Bahasa Inggris materi Procedure text bagi siswa kelas IXB SMP Negeri 1 Boyolali pada Semester1 tahun 2018/2019. Dari kondisi awal sikap jujur dalam mengerjakan tugas rendah ke kondisi akhir menjadi tinggi dan hasil belajar Bahasa Inggris materi Procedure text dari kondisi awal rata-rata nilai $77 \mathrm{ke}$ kondisi akhir rata-rata menjadi 86 naik 9 poin atau $11.68 \%$.

Kata kunci: Sikap Jujur, Procedure text, Hasil Belajar, Project Based Learning, Media Powerpoint

\section{Pendahuluan}

Sikap jujur merupakan salah satu komponen kompetensi sosial yang diharapkan dikuasai oleh siswa untuk membentuk sikap yang baik. Sikap jujur sangat diperlukan dalam keberhasilan pencapaian tujuan pembelajaran. Namun demikian setelah dilakukan pembelajaran bagi siswa kelas IXB SMP Negeri 1 Boyolali pada semester 1 tahun 2018/2019 pada kondisi awal ditemukan bahwa sikap jujur dalam mengerjakan tugas materi Procedure text masih rendah. Hal ini dapat dilihat pada hasil pengamatan pembelajaran pada kondisi awal ketika siswa mengerjakan tugas yang diberikan oleh peneliti pada materi tersebut. Masih banyak siswa yang tidak jujur. Mereka minta bantuan temannya, masih banyak siswa yang menjiplak hasil karya temannya, masih banyak siswa yang bertanya kepada temannya. Begitu juga setelah dilakukan ulangan harian pada kondisi awal, banyak siswa yang tanya kepada temannya, masih tengak-tengok, belum bisa mengerjakan dengan tenang. Setelah ulangan harian pada kondisi awal dikoreksi ditemukan bahwa bahwa nilai tertinggi 90, nilai terendah 60 , rata-rata 77 , tuntas 16 orang, belum tuntas 12 orang. Hal ini masih jauh dari target yang harapan oleh sekolah tentang keberhasilan siswa. Kondisi semacam ini dapat dilihat pada hasil ulangan harian pada kondisi awal.

Sikap jujur siswa dalam mengerjakan tugas dan hasil belajar Bahasa Inggris materi Procedure text masih rendah, mungkin disebabkan karena guru dalam memilih model dan media pembelajaran belum tepat, sehingga siswa tidak tertarik untuk mengikuti pembelajaran. Hal tersebut di atas disadari setelah hasil belajar siswa rendah. Oleh karena itu perlu dicari apa penyebab sikap jujur dalam mengerjakan tugas dan hasil belajar Bahasa Inggris materi Procedure text rendah.

Diharapkan bahwa sikap jujur dalam mengerjakan tugas dan hasil belajar Bahasa Inggris materi Procedure text dapat meningkat dan rata-rata jauh di atas KKM yang telah ditetapkan oleh kurikulum sekolah, dengan melakukan kegiatan pembelajaran yang bermakna dengan menggunakan model dan media pembelajaran yang tepat.

Berbagai model dan media pembelajaran telah digunakan, namun hasilnya belum sesuai yang diharapkan. Oleh karena itu, perlu menerapkan model dan media pembelajaran yang sesuai dengan materi yang diajarkan, yang sangat diperlukan dalam perbaikan pembelajaran yang akhirnya hasil belajar siswa dapat meningkat.

Berkenaan dengan hal tersebut, maka dipandang sangat perlu untuk memberikan solusi tentang peningkatan sikap jujur dalam mengerjakan tugas dan hasil belajar Bahasa Inggris materi Procedure text melalui penggunaan model Project Based Learning berbantuan media Powerpoint. Penggunaan model pembelajaran ini dilakukan dengan dua tahapan, yaitu: penggunaan Project Based Learning berbantuan media Powerpoint dalam kelompok besar yang terdiri atas 7 siswa dan kelompok kecil yang terdiri atas 4 siswa. Dengan menggunakan model pembelajaran Project Based Learning berbantuan media powerpoint ini, diharapkan sikap jujur dalam mengerjakan tugas dan hasil belajar Bahasa 
Inggris materi Procedure text bagi siswa kelas IXB SMP Negeri 1 Boyolali pada semester 1 tahun 2018/2019 dapat meningkat.

Berdasarkan latar belakang masalah di atas, dapat diidentifikasi permasalahan sebagai berikut. Mengapa sikap jujur dalam mengerjakan tugas dan hasil belajar Bahasa Inggris materi Procedure text bagi siswa kelas IXB SMP Negeri 1 Boyolali pada semester 1 tahun 2018/2019 rendah. Setelah itu masalah dapat dirumuskan sebagai berikut. Apakah melalui penggunaan model Project Based Learning berbantuan media Powerpoint dapat meningkatkan sikap jujur dalam mengerjakan tugas dan hasil belajar Bahasa Inggris materi Procedure text bagi siswa kelas IXB SMP Negeri 1 Boyolali pada semester 1 tahun 2018/2019?

Sikap jujur seseorang dipengaruhi banyak faktor, antara lain: kecerdasan, bakat, perasaan, emosi, dan kesehatan mental. Kecerdasan atau inteligensi menunjuk kepada cara individu berbuat, apakah berbuat dengan cara yang cerdas atau kurang cerdas atau tidak cerdas sama sekali. Cepat dan tepat dalam memahami unsur-unsur yang ada dalam suatu situasi, dalam melihat hubungan antar unsur, dalam menarik kesimpulan serta dalam mengambil keputusan atau tindakan (Sukmadinata, 2004:93).

Keberhasilan suatu pendidikan ditentukan oleh beberapa komponen. Salah satu komponen yang sangat penting adalah kejujuran. Siswa harus memiliki sikap jujur dalam belajar, mengerjakan tugas, dan penilaian. Kejujuran dalam mengerjakan tugas dipengaruhi oleh beberapa faktor. Faktor-faktor yang mempengaruhi sikap jujur adalah: percaya diri, disiplin, kreativitas, dan tanggung jawab.

Selain yang sudah disebutkan sebelumnya, faktor yang mempengaruhi sikap jujur adalah tanggung jawab. Tanggung jawab adalah kesadaran manusia akan tingkah laku atau perbuatannya yang disengaja maupun yang tidak disengaja. Tanggung jawab juga berarti berbuat sebagai perwujudan kesadaran akan kewajiban. Tanggung jawab bersifat kodrati, artinya sudah menjadi bagian hidup dari manusia bahwa setiap manusia dibebani dengan tanggung jawab (Purwanti, 2018:273274).

A procedure is a piece of text that gives us instruction for doing something. The purpose of a procedure text type is to explain how something can be done (Anderson, 2003:50). Teks prosedur adalah jenis teks yang banyak dijumpai di sekitar kita, dalam "manual", resep-resep masakan, aturan-aturan, dan berbagai teks "how to" yang lain (Depdiknas, 2005:3). Jenis teks prosedur memberitahu kita bagaimana sesuatu dikerjakan melalui serangkaian langkah atau tindakan (Derewianka, 1990 dalam Depdiknas, 2005:3).

Procedure is a text that shows a process in order. Its social function is to describe how something is completely done through a sequence of series. Generic Structure of Procedure: (1) Goal: showing the purpose; (2) Material: Telling the needed materials; (3) Step 1-end: Describing the steps to achieve the purpose. Language Feature of Procedure: (1)Using temporal conjunction; (2)Using action verb; (3) Using imperative sentence; (4)Using Simple Present Tense.

Untuk mengukur hasil belajar Bahasa Inggris dapat dilakukan dengan dua cara, yaitu dengan tes dan non tes. Tes dapat dilakukan secara lisan, tertulis dan perbuatan. Tes tertulis yang digunakan untuk mengetahui hasil belajar yang dapat dilakukan pada pokok bahasan tertentu, tengah semester, akhir semester, atau akhir kegiatan pembelajaran. Non tes dilakukan dengan cara pengamatan, dokumentasi dan portofolio. Portofolio ini akan sangat bermanfaat baik bagi guru maupun siswa dalam melakukan penilaian proses (Sukmara, 2005:118-119).

Model pembelajaran dapat didefinisikan sebagai desain pengajaran 8 yang menggambarkan proses khusus dan penyediaan iklim belajar tertentu yang dapat membuat siswa berinteraksi sedemikian rupa sehingga 
terjadi perubahan perilaku misalnya dari tidak tahu menjadi tahu, dsb. (School of Education, PU: 2011). Pendapat lain menyebutkan bahwa model pembelajaran adalah standar tingkah laku dalam mengajar yang teridentifikasi agar dapat mencapai situasi mengajar tertentu. Pakar pendidikan seperti Joyce dan Marsha Weil's (1980) menyebutkan bahwa model pembelajaran adalah suatu rancangan atau pola yang dapat digunakan untuk membentuk kurikulum (pembelajaran dalam jangka waktu lama), untuk mendesain bahan-bahan pembelajaran dan untuk mengarahkan guru mengajar serta setting lainnya di dalam kelas.

Media adalah berbagai jenis komponen dalam lingkungan siswa yang dapat merangsangnya untuk belajar (Gagne dalam Depdiknas, 2005:12). Media adalah segala alat fisik yang dapat menyajikan pesan serta merangsang siswa untuk belajar (Briggs dalam Depdiknas, 2005:12). Media adalah segala sesuatu yang dapat digunakan untuk menyalurkan pesan dari pengirim ke penerima sehingga dapat merangsang pikiran, perasaan, perhatian dan minat serta perhatian siswa sedemikian rupa sehingga proses belajar terjadi (Sadiman et al dalam Depdiknas, 2005:13) Levie \& Lentz (1982) dalam Arsyad (2003:16), mengemukakan empat fungsi media pengajaran, khususnya media visual adalah fungsi atensi, fungsi afektif, fungsi kognitif, dan fungsi kompensatoris.

Pembelajaran Berbasis Projek (Project Based Learning) adalah kegiatan pembelajaran yang menggunakan projek sebagai proses pembelajaran untuk mencapai kompetensi sikap, pengetahuan, dan keterampilan. Penekanan pembelajaran terletak pada aktivitas-aktivitas peserta didik untuk menghasilkan produk dengan menerapkan keterampilan meneliti, menganalisis, membuat, sampai dengan mempresentasikan produk pembelajaran berdasarkan pengalaman nyata. Produk yang dimaksud adalah hasil projek dalam bentuk desain, skema, karya tulis, karya seni, karya teknologi/prakarya, dan lain-lain. Pendekatan ini memperkenalkan peserta didik untuk bekerja secara mandiri maupun berkelompok dalam menghasilkan produk nyata. Tujuan Pembelajaran Berbasis Projek adalah sebagai berikut. (1) Memperoleh pengetahuan dan keterampilan baru dalam pembelajaran. (2) Meningkatkan kemampuan peserta didik dalam menyelesaikan projek. (3) Membuat peserta didik lebih aktif dalam menyelesaikan projek yang kompleks dengan hasil produk nyata berupa barang atau jasa. (4) Mengembangkan dan meningkatkan keterampilan peserta didik dalam mengelola sumer/bahan/alat untuk menyelesaikan tugas/ projek. (5) Meningkatkan kolaborasi peserta didik khususnya pada PBP yang bersifat kelompok (Kemdikbud, 2014:11).

Prinsip-prinsip Pembelajaran Berbasis Projek (PBP) adalah sebagai berikut. (1) Pembelajaran berpusat pada peserta didik yang melibatkan tugas-tugas projek pada kehidupan nyata untuk memperkaya pembelajaran. (2) Tugas projek menekankan pada kegiatan penelitian berdasarkan suatu tema atau topik yang telah ditentukan dalam pembelajaran. (3) Tema atau topik yang dibelajarkan dapat dikembangkan dari suatu kompetensi dasar tertentu atau gabungan beberapa kompetensi dasar dalam suatu mata pelajaran. Oleh karena itu, tugas projek dalam satu semester dibolehkan hanya satu penugasan dalam satu mata pelajaran. (4) Penyelidikan atau eksperimen dilakukan secara otentik dan menghasilkan produk nyata yang telah dianalisis dan dikembangkan berdasarkan tema/topik yang disusun dalam bentuk produk (laporan atau hasil karya). Produk tersebut selanjutnya dikomunikasikan untuk mendapat tanggapan dan umpan balik untuk perbaikan produk. (5) Pembelajaran dirancang dalam pertemuan tatap muka dan tugas mandiri dalam fasilitasi dan monitoring oleh guru. Pertemuan tatap muka dapat dilakukan di awal pada langkah penentuan projek dan di akhir pembelajaran pada langkah penyusunan laporan dan presentasi/publikasi hasil projek, serta evaluasi proses dan hasil projek (Kemdikbud, 2014:12).

Dalam PBP, peserta didik diberikan tugas dengan mengembangkan tema/topik dalam 
pembelajaran dengan melakukan kegiatan projek yang realistis. Di samping itu, penerapan pembelajaran berbasis projek mendorong tumbuhnya kreativitas, kemandirian, tanggung jawab, kepercayaan diri, serta berpikir kritis dan analitis pada peserta didik. Secara umum, langkah-langkah PBP dapat dijelaskan sebagai berikut. (1) Penentuan projek. Pada langkah ini, peserta didik menentukan tema/ topik projek bersama guru. (2) Perancangan langkah-langkah penyelesaian projek.

Peserta didik merancang langkah-langkah kegiatan penyelesaian projek dari awal sampai akhir beserta pengelolaannya. (3) Penyusunan jadwal pelaksanaan projek. Peserta didik dengan pendampingan guru melakukan penjadwalan semua kegiatan yang telah dirancang. (4) Penyelesaian projek dengan fasilitasi dan monitoring guru. Langkah ini merupakan pelaksanaan rancangan projek yang telah dibuat.

(5) Penyusunan laporan dan presentasi/ publikasi hasil projek. Hasil projek dalam bentuk produk, baik itu berupa produk karya tulis, desain, karya teknologi/prakarya, dan lain-lain dipresentasikan dan atau dipublikasikan kepada peserta didik yang lain dan guru atau masyarakat dalam bentuk presentasi, publikasi. (6) Evaluasi proses dan hasil projek. Guru dan peserta didik pada akhir proses pembelajaran melakukan refleksi terhadap aktivitas dan hasil tugas projek. Pada tahap ini juga dilakukan umpan balik terhadap proses dan produk yang telah dilakukan (Depdikbud, 2014:13).

\section{Metode Penelitian}

Penelitian ini dilaksanakan selama enam bulan, yaitu mulai bulan Januari 2018 sampai dengan bulan Juni 2018 di kelas IXB SMP Negeri 1 Boyolali pada semester 1 tahun 2018/2019.

Subjek dalam penelitian ini adalah siswa kelas IXB SMP Negeri 1 Boyolali pada semester 1 tahun 2018/2019. Jumlah siswa dalam kelas ini adalah 28 siswa yang terdiri atas 6 siswa laki-laki dan 22 siswa perempuan.

Objek dalam penelitian ini adalah sikap jujur dalam mengerjakan tugas, hasil belajar Bahasa Inggris materi Procedure text, dan Project Based Learning berbantuan media Powerpoint yang digunakan dalam pembelajaran Bahasa Inggris bagi siswa kelas IXB SMP Negeri 1 Boyolali pada semester 1 tahun 2018/2019.

Sumber data dalam penelitian ini adalah data tentang sikap jujur dalam mengerjakan tugas dan hasil belajar Bahasa Inggris materi Procedure text pada kondisi awal, data tentang sikap jujur dalam mengerjakan tugas dan hasil belajar Bahasa Inggris materi Procedure text pada siklus I, data tentang sikap jujur dalam mengerjakan tugas dan hasil belajar Bahasa Inggris materi Procedure text pada siklus II.

Pengumpulan data dilakukan dengan cara teknik studi dokumentasi pada kondisi awal, teknik observasi dan teknik tes pada siklus I dan siklus II. Alat pengumpulan data yaitu dokumen catatan personal siswa, dokumen daftar nilai, lembar observasi, dan butir soal.

Validasi data tentang sikap jujur dalam mengerjakan tugas dalam pelajaran Bahasa Inggris materi Procedure text dengan teknik observasi yang dilakukan oleh peneliti dengan berkolabrasi dengan teman sejawat. Validasi data tentang hasil belajar Bahasa Inggris materi Procedure text dilakukan dengan tes yang dilengkapi kisi-kisi soal, butir soal yang baik, kunci jawaban, dan pedoman penilaian.

Analisis data yang dilakukan dengan membandingkan tentang sikap jujur dalam mengerjakan tugas pada kondisi awal dengan kondisi pada siklus I dan siklus II. Membandingkan nilai rata-rata hasil belajar Bahasa Inggris materi Procedure text pada kondisi awal dengan siklus I dan siklus II. Setelah membandingkan kondisi awal dengan kondisi pada siklus I dan siklus II, maka dilanjutkan refleksi untuk menentukan tindak lanjut.

Target yang diharapkan dalam tindakan ini adalah adanya peningkatan yang tinggi tentang sikap jujur dalam mengerjakan tugas dalam pelajaran Bahasa Inggris materi Procedure text bagi siswa kelas IXB SMP Negeri 1 Boyolali pada semester 1 tahun 
2018/2019 dan ada peningkatan rata-rata nilai hasil belajar Bahasa Inggris materi Procedure text bagi siswa kelas IXB SMP Negeri 1 Boyolali pada semester 1 tahun 2018/2019 sebesar 5 poin.

Langkah pertama dalam melakukan tindakan yaitu menentukan metode penelitian. Langkah kedua yaitu menentukan tindakan dalam siklus. Penelitian tindakan kelas ini menggunakan dua siklus yaitu siklus I dan siklus II. Tindakan yang dilakukan ada dua macam yaitu penggunaan Project Based Learning berbantuan media Powerpoint dalam kelompok besar yang terdiri atas 7 siswa dan kelompok kecil yang terdiri atas 4 siswa. Penggunaan Project Based Learning berbantuan media Powerpoint dalam kelompok besar dilakukan pada siklus I, sedangkan penggunaan Project Based Learning berbantuan media Powerpoint dalam kelompok kecil dilakukan pada siklus II. Langkah ketiga yaitu menentukan tahapan tindakan pada setiap siklus. Setiap siklus ada empat tahapan tindakan yaitu: perencanaan (planning), tindakan (acting), pengamatan (observing), dan refleksi (reflecting).

\section{Hasil Penelitian dan Pembahasan}

\section{Deskripsi Kondisi Awal}

a. Sikap jujur dalam mengerjakan tugas.

Setelah dilakukan pengamatan pada kondisi awal, diketahui bahwa sikap jujur dalam mengerjakan tugas $\mathrm{Ba}-$ hasa Inggris materi Procedure text bagi siswa kelas IXB SMP Negeri 1 Boyolali pada semester 1 tahun 2018/2019 masih rendah. Mungkin hal ini disebabkan karena dalam penyampaian pembelajaran belum menggunakan model dan media pembelajaran yang sesuai dengan materi yang disajikan sehingga hasil belajar siswa rendah.

b. Hasil Belajar Bahasa Inggris

Data hasil belajar Bahasa Inggris materi Procedure text diambil dari daftar nilai ulangan harian. Rata-ra- ta nilai pada ulangan harian pertama adalah 76 dan pada ulangan harian juga kedua 77 . Nilai ini masih di bawah Kriteria Ketuntasan Minimal yang ditetapkan yaitu 78. Data nilai ulangan harian pada kondisi awal dapat dilihat pada tabel di bawah.

Tabel 1. Nilai Penilaian Harian Kondisi Awal

\begin{tabular}{clcc}
\hline No & \multicolumn{1}{c}{ Uraian } & $\begin{array}{c}\text { Ulangan } \\
\text { Harian 1 }\end{array}$ & $\begin{array}{c}\text { Ulangan } \\
\text { Harian 2 }\end{array}$ \\
\hline 01 & Nilai Terendah & 55 & 60 \\
02 & Nilai Tertinggi & 95 & 90 \\
03 & Nilai Rerata & 76 & 77 \\
04 & Rentang Nilai & 40 & 30 \\
05 & Tuntas & 16 & 16 \\
06 & Belum tuntas & 12 & 12 \\
\hline
\end{tabular}

Dari Dari tabel di atas dapat diketahui bahwa: nilai terendah ada peningkatan 5 poin, nilai tertinggi ada penurunan 5 poin, nilai rerata ada peningkatan 1 poin, dan rentang nilai ada penurunan 10 poin. Siswa tuntas maupun belum tuntas tetap.

\section{Deskripsi Hasil Siklus I}

a. Hasil Pengamatan

1) Sikap jujur dalam mengerjakan tugas.

Dari hasil pengamatan pada siklus I siswa mengungkapkan perasaan apa adanya saat menyampaikan gagasan pada saat diskusi kelompok agak banyak; siswa mengakui kesalahan atau kekurangan yang dimilikinya agak banyak; siswa tidak meniru atau menyontek pekerjaan teman agak banyak; siswa tidak menjadi plagiat agak banyak; siswa membuat laporan berdasarkan data agak banyak; siswa mengerjakan tugas tanpa bantuan orang lain agak banyak.

2) Hasil Belajar Bahasa Inggris 
Hasil belajar Bahasa Inggris materi Procedure text pada siklus I dapat diketahui setelah dilaksanakan ulangan harian pertama. Rekap nilai ulangan harian pada siklus I dapat dilihat pada tabel.

Tabel 2. Nilai Penilaian Harian Siklus I

\begin{tabular}{clc}
\hline No & \multicolumn{1}{c}{ Uraian } & UH Siklus I \\
\hline 01 & Nilai Terendah & 72 \\
02 & Nilai Tertinggi & 93 \\
03 & Nilai Rerata & 86 \\
04 & Rentang Nilai & 21 \\
05 & Tuntas & 26 \\
06 & Belum tuntas & 2 \\
\hline
\end{tabular}

Dari tabel 2 di atas dapat diketahui bahwa nilai hasil belajar Bahasa Inggris materi Procedure text bagi siswa kelas IXB SMP Negeri 1 Boyolali pada semester 1 tahun 2018/2019 pada siklus I sebagai berikut: nilai terendah 72 , nilai tertinggi 93, nilai rerata 86, dan rentang nilai 21 , tuntas 26 , belum tuntas 2.

b. Refleksi

1) Sikap jujur dalam mengerjakan tugas.

Deskripsi kualitatif tentang siswa mengungkapkan perasaan apa adanya saat menyampaikan gagasan pada saat diskusi kelompok dari sedikit menjadi agak banyak; siswa mengakui kesalahan atau kekurangan yang dimilikinya dari sedikit menjadi agak banyak; siswa tidak meniru atau menyontek pekerjaan teman dari sedikit menjadi agak banyak; siswa tidak menjadi plagiat dari sedikit menjadi agak banyak; siswa membuat laporan berdasarkan data dari sedikit menjadi agak banyak; siswa mengerjakan tugas tanpa bantuan orang lain dari sedikit menjadi agak banyak. Dengan demikian ada peningkatan sikap jujur siswa dalam mengerjakan tugas.

2) Hasil Belajar Bahasa Inggris Refleksi mengenai hasil belajar Bahasa Inggris materi Procedure text dari kondisi awal sampai siklus I didasarkan pada hasil studi dokumentasi. Studi dokumentasi dilakukan antara daftar nilai ulangan harian pada kondisi awal dengan ulangan harian pada siklus I.

Tabel 3. Refleksi Hasil Belajar Bahasa Inggris

\begin{tabular}{lll}
\multicolumn{3}{c}{ Siklus I } \\
\hline No & \multicolumn{1}{c}{ Kondisi Awal } & \multicolumn{1}{c}{ Siklus I } \\
\hline & Ulangan Harian & Ulangan Harian \\
01 & Pada Kondisi Awal: & Pada Siklus I: \\
02 & Nilai Terendah : 60 & Nilai Terendah : 72 \\
03 & Nilai Tertinggi : 90 & Nilai Tertinggi : 93 \\
04 & Nilai Rerata $: 77$ & Nilai Rerata $: 86$ \\
05 & Tuntas $: 16$ & Tuntas $: 26$ \\
& Belum tuntas $: 12$ & Belum tuntas $: 2$ \\
\hline
\end{tabular}

Deskripsi komparatif nilai terendah ada peningkatan 12 poin dari 60 menjadi 72 , nilai tertinggi ada peningkatan 3 poin dari 90 menjadi 93, nilai rata-rata ada peningkatan 9 poin dari 77 menjadi 86, siswa tuntas ada peningkatan 10 poin dari 16 menjadi 26 , dan siswa belum tuntas turun 10 poin dari 12 menjadi 2. Berdasarkan deskripsi komparatif tersebut, nilai tertinggi, nilai terendah, rata-rata nilai, dan siswa tuntas ada peningkatan, sedangkan siswa belum tuntas ada penurunan.

\section{Deskripsi Hasil Siklus II}

a. Hasil Pengamatan

1) Sikap jujur dalam mengerjakan tugas.

Deskripsi kualitatif tentang siswa mengungkapkan perasaan apa adanya saat men- 
yampaikan gagasan pada saat diskusi kelompok banyak; siswa mengakui kesalahan atau kekurangan yang dimilikinya banyak; siswa tidak meniru atau menyontek pekerjaan teman banyak; siswa tidak menjadi plagiat banyak; siswa membuat laporan berdasarkan data banyak; siswa mengerjakan tugas tanpa bantuan orang lain banyak.

2) Hasil Belajar Bahasa Inggris Hasil belajar Bahasa Inggris materi Procedure text pada siklus II dapat diketahui setelah dilaksanakan ulangan harian kedua. Untuk mengetahui hasil belajar Bahasa Inggris pada siklus II, maka peneliti melakukan studi dokumentasi pada daftar nilai ulangan harian kedua pada pembelajaran siklus II. Rekap nilai ulangan harian dapat dilihat pada tabel.

Tabel 4. Nilai Penilaian Harian Siklus II

\begin{tabular}{clc}
\hline No & \multicolumn{1}{c}{ Uraian } & UH Sikuls II \\
\hline 01 & Nilai Terendah & 78 \\
02 & Nilai Tertinggi & 90 \\
03 & Nilai Rerata & 86 \\
04 & Rentang Nilai & 12 \\
05 & Tuntas & 28 \\
06 & Belum tuntas & 0 \\
\hline
\end{tabular}

Dari tabel di atas dapat diketahui bahwa nilai hasil belajar Bahasa Inggris materi Procedure text bagi siswa kelas IXB SMP Negeri 1 Boyolali pada semester 1 tahun 2018/2019 pada siklus II sebagai berikut: nilai terendah 78 , nilai tertinggi 90 , nilai rerata 86 , rentang nilai 12 , tuntas 28 , belum tuntas 0 .

b. Refleksi

1) Sikap jujur dalam mengerjakan tugas.
Deskripsi kualitatif tentang siswa mengungkapkan perasaan apa adanya saat menyampaikan gagasan pada saat diskusi kelompok dari agak banyak menjadi banyak; siswa mengakui kesalahan atau kekurangan yang dimilikinya dari agak banyak menjadi banyak; siswa tidak meniru atau menyontek pekerjaan teman dari agak banyak menjadi banyak; siswa tidak menjadi plagiat dari agak banyak menjadi banyak; siswa membuat laporan berdasarkan data dari agak banyak menjadi banyak; siswa mengerjakan tugas tanpa bantuan orang lain dari agak banyak menjadi banyak. Dengan demikian ada peningkatan sikap jujur siswa yang banyak dalam mengerjakan tugas materi Procedure text.

2) Hasil Belajar Bahasa Inggris

Refleksi mengenai hasil belajar Bahasa Inggris materi Procedure text dapat dilihat pada tabel.

Tabel 5. Refleksi Hasil Belajar Bahasa Inggris Pada Siklus II

\begin{tabular}{llll}
\hline No & \multicolumn{2}{c}{ Siklus I } & \multicolumn{2}{c}{ Siklus II } \\
\hline & Ulangan Harian & Ulangan \\
& Pada & Hadian \\
01 & Siklus I: & Siklus II: \\
02 & Nilai Terendah : 72 & Nilai Terendah : 78 \\
03 & Nilai Tertinggi : 93 & Nilai Tertinggi : 90 \\
04 & Nilai Rerata : $: 86$ & Nilai Rerata $: 86$ \\
05 & Tuntas $: 26$ & Tuntas $: 28$ \\
& Belum tuntas $: 2$ & Belum tuntas $: 0$ \\
\hline
\end{tabular}

Deskripsi komparatif nilai terendah meningkat sebesar 6 poin dari 72 menjadi 78 , nilai tertinggi turun 3 poin dari 93 menjadi 90 , nilai rata-rata tetap, siswa tuntas meningkat 2 poin dari 26 menjadi 28, dan siswa belum tuntas turun 2 poin dari 
2 menjadi 0.

\section{Pembahasan}

1. Sikap jujur dalam mengerjakan tugas. Hasil penelitian tentang sikap jujur dalam mengerjakan tugas diperoleh dengan melakukan pembahasan hasil pengamatan. Pembahasan mengenai sikap jujur dalam mengerjakan tugas dari kondisi awal, siklus I, sampai siklus II atau kondisi akhir.

Deskripsi kualitatif tentang siswa mengungkapkan perasaan apa adanya saat menyampaikan gagasan pada saat diskusi kelompok dari sedikit menjadi banyak; siswa mengakui kesalahan atau kekurangan yang dimilikinya dari sedikit menjadi banyak; siswa tidak meniru atau menyontek pekerjaan teman dari sedikit menjadi banyak; siswa tidak menjadi plagiat dari sedikit menjadi banyak; siswa membuat laporan berdasarkan data dari sedikit menjadi banyak; siswa mengerjakan tugas tanpa bantuan orang lain dari sedikit menjadi banyak. Dengan demikian ada peningkatan yang tinggi tentang sikap jujur siswa dalam mengerjakan tugas materi Procedure text.

2. Hasil Belajar Bahasa Inggris

Hasil penelitian tentang hasil belajar Bahasa Inggris materi Procedure text dapat diperoleh dengan melakukan studi dokumentasi. Pembahasan mengenai hasil belajar Bahasa Inggris dari kondisi awal, siklus I, sampai dengan siklus II atau kondisi akhir dapat dilihat pada tabel.

Dari kondisiawal ke kondisiakhir terdapat peningkatan hasil belajar dari rata-rata
77 menjadi 86. Dengan demikian ada peningkatan sebesar 9 poin atau $11.68 \%$.

Tabel 6. Hasil Belajar Bahasa Inggris

\begin{tabular}{llll}
\hline No & $\begin{array}{c}\text { Kondisi } \\
\text { awal }\end{array}$ & \multicolumn{1}{c}{ Siklus I } & $\begin{array}{c}\text { Siklus II/ } \\
\text { Kondisi } \\
\text { akhir }\end{array}$ \\
\hline 01 & Nilai Ter- & Nilai & Nilai \\
& endah: 60 & Terendah & Terendah: \\
02 & Nilai Tert- & $: 72$ & 78 \\
& inggi: 90 & Nilai & Nilai \\
03 & N Rerata: & Tertinggi & Tertinggi: \\
& 77 & $: 93$ & 90 \\
& & N Rerata: 86 & N Rerata: \\
& & & 86 \\
\hline
\end{tabular}

\section{Hasil Tindakan}

Melalui penggunaan model Project Based Learning berbantuan media Powerpoint dapat meningkatkan sikap jujur dalam mengerjakan tugas dan hasil belajar Bahasa Inggris materi Procedure text bagi siswa kelas IXB SMP Negeri 1 Boyolali pada semester 1 tahun 2018/2019. Dari kondisi awal sikap jujur dalam mengerjakan tugas rendah ke kondisi akhir menjadi tinggi dan hasil belajar Bahasa Inggris materi Procedure text dari kondisi awal rata-rata nilai 77 ke kondisi akhir ratarata menjadi 86 atau naik 9 poin atau $11.68 \%$.

\section{Simpulan}

Berdasarkan hasil penelitian dan pembahasan dapat disimpulkan, baik secara teoritik maupun empirik menyebutkan bahwa melalui penggunaan model Project Based Learning berbantuan media Powerpoint dapat meningkatkan sikap jujur dalam mengerjakan tugas dan hasil belajar Bahasa Inggris materi Procedure text bagi siswa kelas IXB SMP Negeri 1 Boyolali pada semester 1 tahun 2018/2019.

\section{Daftar Pustaka}

Anderson, Mark and Kathy. 2003. Text Types in English. Malaysia: Macmillian Education Australia Pty Ltd

Asra \& Sumiati. 2009. Metode Pembelajaran. Bandung: CV Wacana Prima.

Ayan, Jordan E. 2002. Bengkel Sikap jujur, Jakarta: Penerbit Kaifa. . 2004. Kurikulum 2004 Sekolah Menengah Pertama. Jakarta: Dirjen Dikdasmen. 
2005. Standar Nasional Pendidikan. Solo: CV. Kharisma.

. 2005. Materi Pelatihan Terintegrasi Bahasa Inggris Buku I. Jakarta: Dirjen Dikdasmen.

. 2005. Materi Pelatihan Terintegrasi Bahasa Inggris uku II. Jakarta: Dirjen Dikdasmen. . 2006. Standar Kompetensi Lulusan Untuk Pendidikan Dasar dan Menengah. Jakarta: Dirjen Dikdasmen.

Bardi. 2009. Peningkatan Kreativitas dan Hasil Belajar Bahasa Inggris Melalui Pemanfaatan Media Microsoft PowerPoint Bagi Siswa Kelas IXC SMP Negeri 3 Boyolali Pada Semester 1 Tahun 2009/2010.Boyolali: SMP Negeri 3 Boyolali.

Budimansyah, Dasim dkk. Pembelajaran Aktif, Kreatif, Efektif, dan Menyenangkan. Bandung: PT Genesindo.

Djumransjah, H.M. 2006. Filsafat Pendidikan. Malang: Bayumedia Publishing.

Hendro, 2013. Sikap dan Logika. http://hakikatsikap.blogspot.com/, diakses Kamis, 19 Juli 2018 jam 08.10.

https://jperpusfpsiuht.wordpress.com/2015/01/12/kejujuran-dalam-pandangan-psikologi/, diakses Selasa, 3 Juli 2018

Hutagalung, Inge. 2007. Pengembangan Kepribadian. Bekasi: PT Indeks.

Jordan E Ayan. 2002. Bengkel Sikap jujur. Penerbit Kaifa.

Kadzim M.N. 2007. Agar Rencana Selalu Berhasil. Sukoharjo: Samudera.

Kementerian Pendidikan dan Kebudayaan. 2014. Panduan Penguatan Proses Pembelajaran Sekolah Menengah Pertama. Jakarta: Direktorat Pembinaan SMP.

Kurniawan, Arif. https://www.membumikanpendidikan.com/2014/05/hakikat-pendidikannilai-dan-sikap.html, diakses Kamis, 19 Juli 2018 jam 09.29

Lyons, J. 1981. Language and Linguistics. Cambridge: Cambridge University Press.

Majid, Abdul. 2009. Perencanaan Pembelajaran. Bandung: PT Remaja Rosdakarya.

Munandar, Utami. 2004. Pengembangan Emosi dan Sikap jujur. Jakarta : Rineka Cipta

Pandia, H. 2007. Teknologi Informasi dan Komunikasi. Jakarta: Erlangga.

Purwanti, Lestari Ning. 2018. Penguatan Pendidikan Karakter (PPK). Jakarta: Erlangga.

Purwanto, Ngalim. 2009. Administrasi dan Supervisi Pendidikan. Bandung: Penerbit PT Remaja Rosdakarya.

Rasyid, H. \& Mansur. 2009. Penilaian Hasil Belajar. Bandung: CV Wacana Prima.

Rosalin, Elin. 2008. Gagasan Merancang Pembelajaran Kontekstual. Bandung: PT Karsa Mandiri Persada.

Sari, Dwi Putri (2014). Meningkatkan Sikap Jujur Melalui Pemberian Layanan Kelompok Pada Siswa Kelas XI SMA Negeri 1 Selesai Tahun Ajaran 2013/2014. Selesai: SMA Negeri 1 Selesai. http://digilib.unimed.ac.id/7854/, Diakses, sabtu, 21 Juli 2018 jam 09.45

Sukmadinata, H.S. 2004. Landasan Psikologi Proses Pendidikan. Bandung: Remaja Rosdakarya.

Sukmara, Dian. 2003. Implementasi Program Life Skill Dalam Kurikulum Berbasis Kompetensi Pada Jalur Sekolah. Bandung: Mughni Sejahtera.

Susilana, R \& Riyana, C. 2009. Media Pembelajaran. Bandung: CV Wacana Prima. 